\title{
Drying Characteristics of Mint Leaves in Tray Dryer
}

\author{
G. Raviteja ${ }^{1}$, P.S. Champawat ${ }^{2}$, S.K. Jain ${ }^{2}$ and Sagar chavan ${ }^{2 *}$ \\ ${ }^{1}$ FEG Dept., CCSc, UAS, Dharwad, India \\ ${ }^{2}$ PFE Dept. CTAE, MPUAT, Udaipur, India \\ *Corresponding author
}

\begin{tabular}{|c|c|}
\hline & A B S T R A C T \\
\hline \multicolumn{2}{|l|}{ Keywords } \\
\hline $\begin{array}{l}\text { Mint leaves, } \\
\text { Drying, Moisture } \\
\text { diffusivity and } \\
\text { Activation energy }\end{array}$ & \multirow{4}{*}{$\begin{array}{l}\text { Thin layer drying behaviour of mint leaves was investigated in axial flow tray dryer at air } \\
\text { temperatures of } 45,55 \text { and } 65^{\circ} \mathrm{C} \text {. Five different thin layer drying models namely Newton, } \\
\text { Page, Logarithmic, Diffusion approach and Henderson and Pabis models were fitted to } \\
\text { experimental drying data. The highest adjusted } \mathrm{R}^{2} \text { with the lowest standard square error } \\
\text { (SSE) and root mean square error (RMSE) were selected as statistical criteria to evaluate } \\
\text { how well the tested models fit the drying data. Diffusion approach model was considered } \\
\text { to be satisfactory to represent the thin layer drying of mint leaves. Moisture diffusivity } \\
\text { values were varied from } 3.29 \times 10^{-10} \text { to } 6.03 \times 10^{-10} \mathrm{~m} / \mathrm{s} \text {. The temperature dependent } \\
\text { activation energy ( } \mathrm{E}_{\mathrm{a}} \text { ) was determined as } 16.90 \text { and } 12.85 \mathrm{~kJ} / \mathrm{mol} \text { for control and blanched } \\
\text { sample. }\end{array}$} \\
\hline Article Info & \\
\hline $\begin{array}{l}\text { Accepted: } \\
\text { 07 February } 2019 \\
\text { Available Online: }\end{array}$ & \\
\hline & \\
\hline
\end{tabular}

\section{Introduction}

India is the one of the largest producer of vegetables in the world with an annual production of 175 million tonnes from 10.3 million ha with an average productivity of $16.99 \mathrm{t} / \mathrm{ha}$ in the year 2016-17 (Anonymous, 2017). Green leafy vegetables are being used since ancient periods as source of food as they contain many nutrients and minerals which are helpful in maintaining human health. Mint leaves (Mentha spicata $L$.) are perennial herbs and grown all over the world to reap its special herbal characteristics. They are herbaceous; rhizome plants that emit quadrangular green or purple stalks. Several species are shrubby or climbing form or rarely small trees. Mint is also very popular in India and mainly cultivated in southern parts of Himalayan range including Punjab, Himachal Pradesh, Haryana, Uttar Pradesh, Rajasthan, Karnataka and other states of India. Mint leaves are used in both fresh and dried forms in different cuisines. Various authors (Park et al., 2002; Thompson, 2003) have revealed that use of mint leaves in a variety of dishes such as vegetable curries, chutney, fruit salads, vegetable salads, salad dressings, soups, desserts, juices, sherbets etc. Owing to high moisture content, green leafy vegetables are highly perishable and are sold at throw away prices in the peak season resulting in 
heavy losses to the growers due to nonavailability of sufficient storage, transport and proper processing facilities at the production point. Drying is the most common and fundamental method for post-harvest preservation of vegetable because it is a simple method for the quick preservation. Drying of vegetable can be done by two methods one is natural drying i.e. sun or solar drying and another one is mechanical drying. Mechanical drying method includes tray drying, oven drying, fluidised bed drying, freeze drying and micro-wave drying. The main aim of this study is to analyze the drying behaviour of a food product, it is essential to study the drying kinetics of the food.

\section{Materials and Methods}

The fresh mint leaves was procured from the local market of Udaipur, Rajasthan for this investigation. Insect infested, ruined, discoloured, decayed, and wilted leaves were discarded before washing the leaves. The stalks of the leaves were cut from the main branches and the leaves were washed. After washing leaves are spread on tissue paper to remove surface moisture. The residue moisture was evaporated at a room temperature; these leaves were used for further study. Sorted, cleaned and washed leaves were subjected to following treatments before drying: The mint leaves were tied in distracted muslin cloth and kept immersed in boiling water for one minute and cooled immediately under running tap water and mint leaves without treatment considered as Control. The initial moisture content of mint leaves was determined by oven drying method (Ranganna, 2000). The initial moisture contents mint leaves found as, 519.12 and 534.92 per cent $(\mathrm{db})$ for fresh and blanched leaves respectively. The experiment was conducted at air temperature of 45, 55 and $65^{\circ} \mathrm{C}$ at air velocity of $2 \mathrm{~m} / \mathrm{s}$ for tray dryer.

\section{Theoretical considerations}

\section{Drying rate}

The moisture content data recorded during experiments were analyzed to determine the moisture lost from the sample of mint leaves in particular time interval. The drying rates of samples were calculated by following mass balance equation (Kadam et al., 2011):

Drying rate $=\frac{\mathrm{dw}}{\mathrm{dt} \times \mathrm{DM}}$

Where, $d w=$ difference in weight, $\mathrm{dt}=$ difference in time, $\mathrm{DM}=$ dry matter

\section{Moisture ratio}

The moisture ratio was calculated by using the following equation;

Moisture ratio $=\frac{\mathrm{M}-\mathrm{Me}}{\mathrm{Mo} \times \mathrm{Me}}$

Eq-2

Where, $\mathrm{M}=$ Moisture content at any specified time $\mathrm{t}$ (per cent $\mathrm{db}$ ), $\mathrm{M}_{\mathrm{e}}=$ Equilibrium moisture content (per cent $\mathrm{db}$ ), $\mathrm{M}_{0}=$ Initial moisture content (per cent $\mathrm{db}$ ), $\mathrm{M}_{\mathrm{e}}$ in comparison to $\mathrm{M}_{0}$ and $\mathrm{M}$ is very small, hence $\mathrm{M}_{\mathrm{e}}$ can be neglected and moisture ratio can be presented in simplified form (Doymaz and Ismail, 2011; Goyal et al., 2007).

$$
\text { Moisture ratio }=\frac{\mathrm{M}}{\mathrm{Me}}
$$

Eq-3

\section{Mathematical modelling}

The mathematical models viz., Newton, Page, Logarithmic, Diffusion approach and Henderson and Pabis models were selected for fitting the experimental data and these selected models were used to describe the drying curve equations during drying and these models are in Table 1. 
The parameters of all the models were estimated by using MATLAB version 7.11 software packages. The proposed models were fitted on the experimental data using linear regression. The statistical parameters standard square error (SSE) and root mean square error (RMSE) were obtained from the MATLAB version 7.11 software package. The best suitable model was selected on the basis, model shows of highest $\mathrm{R}^{2}$ and lowest standard square error (SSE) and root mean square error (RMSE).

\section{Moisture diffusivity during drying}

The solution of Fick's second law in slab geometry, with the assumption that moisture migration was caused by diffusion, negligible shrinkage, constant diffusion coefficients and temperature was as follows (Crank, 1975).

$M_{R}=\frac{M-M_{\theta}}{M_{0}-M_{e}}=\frac{8}{\pi^{2}} \sum_{n=1}^{\infty} \frac{1}{(2 n+1)^{2}} \exp \left(\frac{(-2 n+1)^{2} \pi^{2} t D_{\text {eff }}}{4 H^{2}}\right)$

Eq-4

Where, $\mathrm{M}_{\mathrm{R}}=$ Moisture ratio, dimensionless, $\mathrm{M}=$ Moisture content at any time, $\mathrm{g} \mathrm{H}_{2} \mathrm{O} / \mathrm{g}$ dry matter, $\mathrm{M}_{0}=$ Initial moisture content, $\mathrm{g}$ $\mathrm{H}_{2} \mathrm{O} / \mathrm{g}$ dry matter, $\mathrm{Me}=$ Equilibrium moisture content, $\mathrm{g}_{2} \mathrm{O} / \mathrm{g}$ dry matter, $\mathrm{D}_{\text {eff }}=$ Effective diffusivity in $\mathrm{m}^{2} / \mathrm{s}, \mathrm{H}=$ Half thickness of mint leaves in, $\mathrm{mm} \mathrm{n}=$ Positive integer, $\mathrm{t}=$ Time (s).

A general form of Eqn. (4) could be written in semi-logarithmic form, as follows.
$\ln \square M_{R} \square=A-B t$
Eq-5

Where, $\mathrm{A}$ is constant and $\mathrm{B}$ is slope,

From Equation (5), a plot of $\ln \left(M_{R}\right)$ versus the drying time gives a straight line with a slope B as,

$$
\text { Slope }=\frac{\pi^{2} D_{\text {eff }}}{4 H^{2}}
$$

The effective diffusivity was determined by substituting value of slope $B$ and half thickness $\mathrm{H}$ from equation (6).

\section{Activation energy}

The Arrhenius Equation was used for the determination of activation energy of the mint leaves. This is due to the dependence of the effective diffusivity on the different drying temperature which predicts appropriately using the equation;

$$
\mathrm{D}_{\text {eff }}=\mathrm{D}_{\circ} \frac{\mathrm{E}_{\mathrm{a}}}{\mathrm{R}(\mathrm{T}+273.15)} \quad \mathrm{Eq}-7
$$

Where $D_{0}$ is the Arrhenius factor $\left(\mathrm{m}^{2} / \mathrm{s}\right), \mathrm{E}_{\mathrm{a}}$ is the activation energy for the moisture diffusion $(\mathrm{kJ} / \mathrm{mol}), \mathrm{R}$ is the universal gas constant $(\mathrm{kJ} / \mathrm{mol} \mathrm{K})$, and $\mathrm{T}$ is drying air temperature $\left({ }^{\circ} \mathrm{C}\right)$.

Linearising the equation gives,

$$
\operatorname{Ln} D_{\text {eff }}=D_{o}\left(-\frac{1_{a}}{R(T+273.15)}\right)
$$

Eq-8

The activation energy $E_{a}$ was obtained by plotting the activation energy was obtained from a graph of $L n D_{\text {eff }}$ versus $1 /$ Tabs and calculation using Eq 8

\section{Results and Discussion}

\section{Moisture ratio curves}

The initial moisture content was not same for all the drying experiments because of blanching treatment. Hence, the drying curves were normalized by converting the moisture content to moisture ratio (MR). The change in moisture ratio with respect to time for different drying temperatures for both treated and control mint leaves is presented in terms of moisture ratio (MR) versus time graphs shown in Figure 1 to 3 . From the Figures it can be seen that the moisture ratio reduced 
exponentially as the drying time increased. Continuous decrease in moisture ratio indicates that diffusion has governed the internal mass transfer. A higher drying air temperature decreased the moisture ratio faster due to the increase in air heat supply rate to the leaves and the acceleration of moisture migration (Demir et al., 2004). It can be seen that there was a variation in drying time from 240 to $390 \mathrm{~min}$ for the range of drying air temperatures 45 to $65^{\circ} \mathrm{C}$ taken for study. Moisture reduction found to be temperature dependent and slow at lower temperature and took more time as compared to drying at higher temperatures. Experimental results showed that drying air temperature is effective parameter for the drying of min leaves. These results were in good agreement with earlier research by Silva et al., (2008) for Coriander leaves and stems, Aghbashlo et al., (2009) for carrots and Premi et al., (2010) for drum stick leaves, Porntewabancha and Siriwongwilaichat (2010) for lettuce leave.

\section{Drying rate curves of mint leaves}

The drying rate as a function of moisture content at different drying air temperature for mint leaves with treatment in tray dryer is shown in Figure 4, 5 and 6. It can be seen that initially the drying rate was more and subsequently it reduced with drying time. It can also be seen that they follow typical drying rate curves. These drying rates continuously decreased with respect to time. Drying rate of control and blanched sample was found to be different at same temperature because blanching increased drying rate due to the elimination of the cellular membrane resistance to water diffusion (Silva et $a l ., 2008)$. From the observation it can be seen that, a constant rate-drying period was not found in drying curves. The entire drying process took place in the falling rate period; the curves typically demonstrated smooth diffusion controlled drying behaviour under all drying temperatures. Moreover, an important influence of air drying temperature on drying rate could be observed in these curves. It is obvious from these curves that the higher the drying temperature, the greater the drying rate, so the highest values of drying rate were obtained during the experiment at $65^{\circ} \mathrm{C}$. These results are similar to the earlier studies outcomes of different vegetables (Akpinar, 2006; Doymaz et al, 2006; Kadam et al., 2011).

\section{Mathematical modelling}

The drying constants and statistical parameters for different models used for convective tray dried mint leaves have been presented in Table 2 and 3 respectively. It was observed that in all models the values of $\mathrm{R}^{2}$ were greater than 0.99 indicating a good fit. The values of coefficient of determination $\left(\mathrm{R}^{2}\right)$ for Diffusion approach model at all levels of temperatures were greater than 0.999 and the values of standard square error (SSE) and root mean square error (RMSE) were in range 0.0004 to 0.0017 and 0.0049 to 0.0141 respectively.

Table.1 Mathematical models used for drying study

\begin{tabular}{|c|c|c|c|}
\hline Model No & Model name & Model & References \\
\hline $\mathbf{1}$ & Newton & $\mathrm{MR}=\exp (-\mathrm{k} \theta)$ & Kadam et al., 2011 \\
\hline $\mathbf{2}$ & Logarithmic & $\mathrm{MR}=\mathrm{a} \exp (-\mathrm{k} \theta)+\mathrm{c}$ & Kadam et al., 2011 \\
\hline $\mathbf{3}$ & Page & $\mathrm{MR}=\exp \left(-\mathrm{k} \theta^{\mathrm{n}}\right)$ & Doymaz., 2006 \\
\hline $\mathbf{4}$ & Diffusion approach & $\mathrm{MR}=\mathrm{a} \exp (-\mathrm{k} \theta)+(1-\mathrm{a}) \exp (-\mathrm{kb} \theta)$ & Kadam et al., 2011 \\
\hline $\mathbf{5}$ & Henderson and Pabis & $\mathrm{MR}=\mathrm{a} \exp (-\mathrm{k} \theta)$ & Kadam et al.,2011 \\
\hline
\end{tabular}


Table.2 Drying constants of selected models

\begin{tabular}{|c|c|c|c|}
\hline & & \multicolumn{2}{|c|}{ Drying constants } \\
\hline Model & Temperature & Control & Blanched \\
\hline \multirow[t]{3}{*}{ Newton } & 45 & $\mathrm{k}=.0015:$ & $\mathrm{k}=0.019 \mathrm{:}$ \\
\hline & 55 & $\mathrm{k}=0.016:$ & $\mathrm{k}=0.020$ \\
\hline & 65 & $\mathrm{k}=0.017:$ & $\mathrm{k}=0.021:$ \\
\hline \multirow[t]{3}{*}{ Logarithmic } & 45 & $\mathrm{k}=0.016 ; \quad \mathrm{a}=0.985$ & $\mathrm{k}=0.019 ; \mathrm{a}=1.022 \mathrm{z}$ \\
\hline & 55 & $\mathrm{k}=0.016 ; \mathrm{a}=0.962:$ & $\mathrm{k}=0.022 ; \mathrm{a}=0.988$ \\
\hline & 65 & $\mathrm{k}=0.017 ; \mathrm{a}=0.971:$ & $\mathrm{k}=0.021 ; \mathrm{a}=1.011$ \\
\hline \multirow[t]{3}{*}{ Page } & 45 & $\mathrm{k}=0.017 ; \mathrm{n}=0.972:$ & $\mathrm{k}=0.013 ; \mathrm{n}=1.089:$ \\
\hline & 55 & $\mathrm{k}=0.024 ; \mathrm{n}=0.904:$ & $\mathrm{k}=0.023 ; \mathrm{n}=0.971:$ \\
\hline & 65 & $\mathrm{k}=0.023 ; \mathrm{n}=0.931:$ & $\mathrm{k}=0.019 ; \mathrm{n}=1.032 \mathrm{:}$ \\
\hline \multirow{3}{*}{$\begin{array}{l}\text { Diffusion } \\
\text { approach }\end{array}$} & 45 & $\mathrm{k}=0.016 ; \mathrm{a}=0.982 ; \mathrm{b}=0.072$ & $\mathrm{k}=0.054 ; \mathrm{a}=-0.203 ; \mathrm{b}=0.403$ \\
\hline & 55 & $\mathrm{k}=0.044 ; \mathrm{a}=0.195 ; \mathrm{b}=0.295$ & $\mathrm{k}=0.023 ; \mathrm{a}=0.928 ; \mathrm{b}=0.242 \mathrm{:}$ \\
\hline & 65 & $\mathrm{k}=0.088 ; \mathrm{a}=0.074 ; \mathrm{b}=0.181:$ & $\mathrm{k}=0.022 ; \mathrm{a}=0.048 ; \mathrm{b}=0.967:$ \\
\hline \multirow{3}{*}{$\begin{array}{c}\text { Henderson and } \\
\text { Pabis }\end{array}$} & 45 & $\mathrm{k}=0.015 ; \mathrm{a}=0.992:$ & $\mathrm{k}=0.019 ; \mathrm{a}=1.023 \mathrm{:}$ \\
\hline & 55 & $\mathrm{k}=0.015 ; \mathrm{a}=0.971:$ & $\mathrm{k}=0.020 ; \mathrm{a}=1.001:$ \\
\hline & 65 & $\mathrm{k}=0.017 ; \mathrm{a}=0.977 \mathrm{:}$ & $\mathrm{k}=0.021 ; \mathrm{a}=1.004:$ \\
\hline
\end{tabular}

Table.3 Statistical results obtained from the selected models

\begin{tabular}{|c|c|c|c|c|c|c|c|}
\hline \multirow[t]{3}{*}{ Model } & \multirow[t]{3}{*}{ Temperature } & \multicolumn{6}{|c|}{ Statistical parameter } \\
\hline & & \multicolumn{3}{|c|}{ Control } & \multicolumn{3}{|c|}{ Blanched } \\
\hline & & SSE & $\mathbf{R}^{2}$ & RMSE & SSE & $\mathbf{R}^{2}$ & RMSE \\
\hline \multirow[t]{3}{*}{ Newton } & 45 & 0.0018 & 0.9993 & 0.0091 & 0.0050 & 0.9980 & 0.0154 \\
\hline & 55 & 0.0067 & 0.9969 & 0.0184 & 0.0040 & 0.9981 & 0.0145 \\
\hline & 65 & 0.0035 & 0.9982 & 0.0139 & 0.0030 & 0.9984 & 0.0133 \\
\hline \multirow[t]{3}{*}{ Logarithmic } & 45 & 0.0008 & 0.9997 & 0.0062 & 0.0035 & 0.9986 & 0.0135 \\
\hline & 55 & 0.0033 & 0.9985 & 0.0135 & 0.0017 & 0.9992 & 0.0101 \\
\hline & 65 & 0.0017 & 0.9991 & 0.0102 & 0.0025 & 0.9987 & 0.0130 \\
\hline \multirow[t]{3}{*}{ Page } & 45 & 0.0014 & 0.9995 & 0.0081 & 0.0014 & 0.9994 & 0.0085 \\
\hline & 55 & 0.0008 & 0.9996 & 0.0064 & 0.0036 & 0.9983 & 0.0142 \\
\hline & 65 & 0.0007 & 0.9996 & 0.0064 & 0.0025 & 0.9987 & 0.0125 \\
\hline \multirow{3}{*}{$\begin{array}{l}\text { Diffusion } \\
\text { approach }\end{array}$} & 45 & 0.0008 & 0.9997 & 0.0063 & 0.0012 & 0.9995 & 0.0081 \\
\hline & 55 & 0.0004 & 0.9998 & 0.0049 & 0.0017 & 0.9992 & 0.0099 \\
\hline & 65 & 0.0006 & 0.9997 & 0.0063 & 0.0030 & 0.9984 & 0.0141 \\
\hline \multirow{3}{*}{$\begin{array}{c}\text { Henderson } \\
\text { and Pabis }\end{array}$} & 45 & 0.0016 & 0.9994 & 0.0088 & 0.0035 & 0.9986 & 0.0132 \\
\hline & 55 & 0.0042 & 0.9980 & 0.0149 & 0.0040 & 0.9981 & 0.0149 \\
\hline & 65 & 0.0020 & 0.9989 & 0.0109 & 0.0030 & 0.9985 & 0.0136 \\
\hline
\end{tabular}

Table.4 Moisture diffusivity values

\begin{tabular}{|c|c|c|}
\hline Treatment & Drying temperature $\left({ }^{\circ} \mathbf{C}\right)$ & Moisture diffusivity $\left(\mathbf{m}^{2} / \mathbf{s}\right)$ \\
\hline \multirow{3}{*}{ Control } & 45 & $3.29 \times 10^{-10}$ \\
\cline { 2 - 3 } & 55 & $3.87 \times 10^{-10}$ \\
\cline { 2 - 3 } & 65 & $4.38 \times 10^{-10}$ \\
\hline \multirow{3}{*}{ Blanched } & 45 & $3.83 \times 10^{-10}$ \\
\cline { 2 - 3 } & 55 & $4.10 \times 10^{-10}$ \\
\cline { 2 - 3 } & 65 & $6.02 \times 10^{-10}$ \\
\hline
\end{tabular}


Fig.1, 2 and 3 showing $\ln (\mathrm{MR})$ verses drying time for tray dried sample at $45^{\circ}, 55^{\circ}$ and $65^{\circ} \mathrm{C}$ temperature; Fig. A, B and C showing moisture ratio curves of mint leaves at 45,55 and $65^{\circ} \mathrm{C}$

Fig. D, E, and F showing Drying rate curves of mint leaves at 45,55 and $65^{\circ} \mathrm{C}$

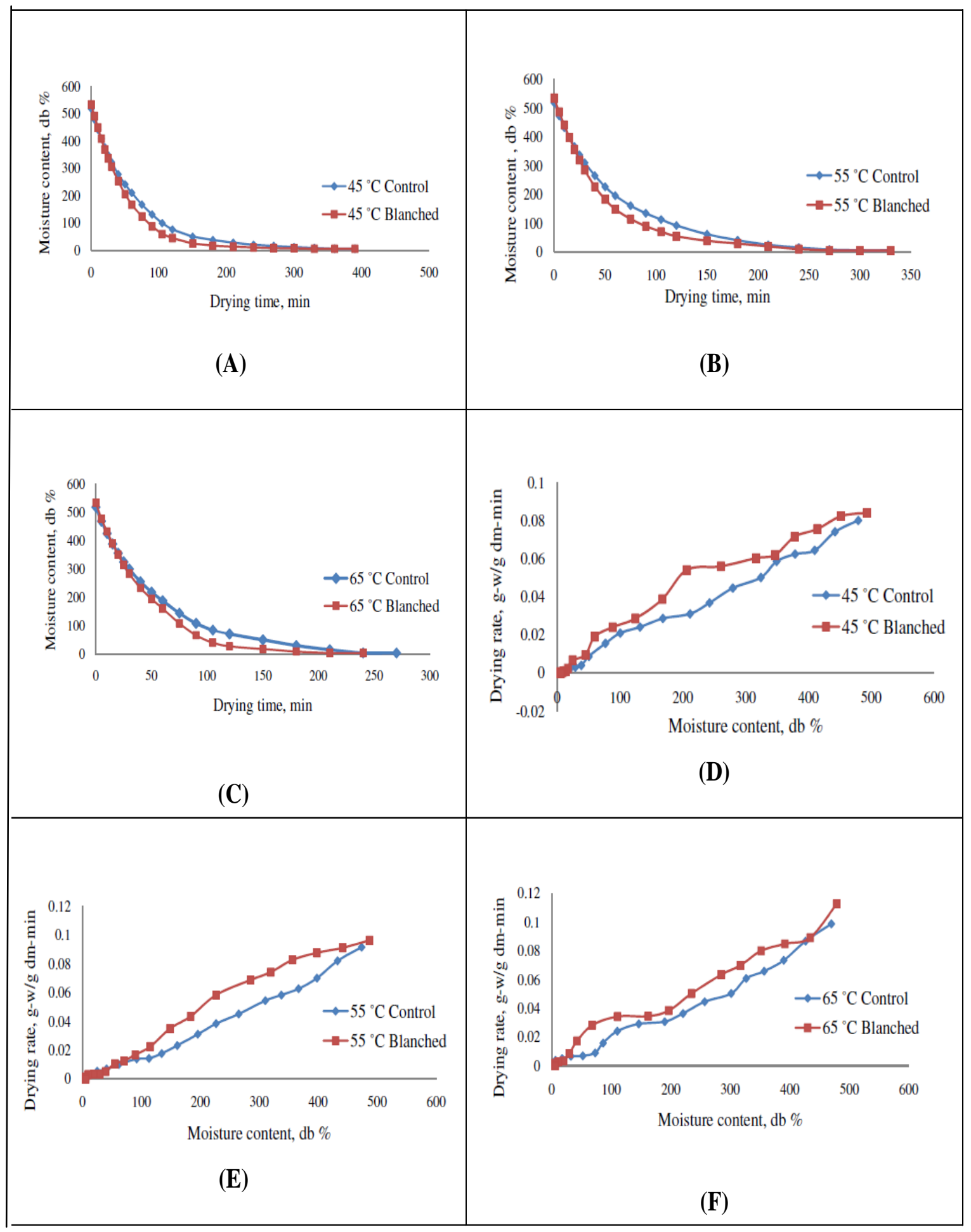


Fig.4 and 5 showing Experimental and predicted values of moisture ratio by diffusion approach model for control and blanched sample at various temperatures

Fig.6 ln (Deff) verses $1 /(\mathrm{T}+273.15)$ for tray dried samples at various temperature

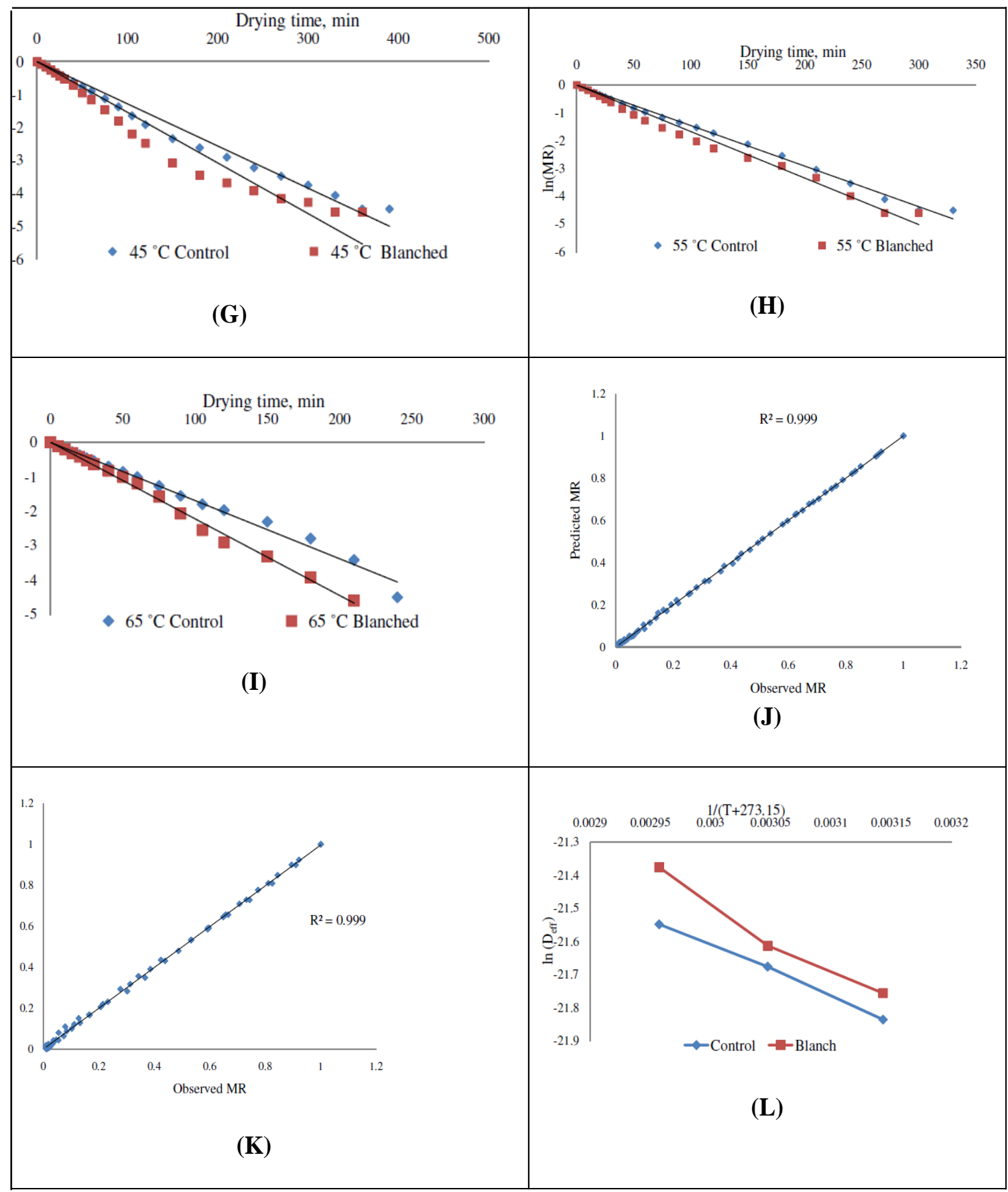

\section{Moisture diffusivity of mint leaves}

The value of moisture diffusivity represented in Table 4. For control mint leaves the moisture diffusivity increased from $3.29 \times 10^{-10}$ to $4.38 \times 10^{-10} \mathrm{~m}^{2} / \mathrm{s}$ as the drying air temperature increased from 45 to $65^{\circ} \mathrm{C}$ and for the blanched mint leaves the moisture 
diffusivity increased from $3.83 \times 10^{-10}$ to $6.03 \times 10^{-10}$. Similar values of moisture diffusivities have been reported by Kadam et al., (2011) for mint leaves and Zakipour and Hamidi, (2011) for the drying of some vegetables increased with increased in drying air temperature and moisture diffusion is an internal process which very much depends on product temperature (Singh and Heldman, 2001).

\section{Activation energy of mint leaves}

Activation energy of tray dried mint leaves found as 16.90 and $12.85 \mathrm{~kJ} / \mathrm{mol}$ for control and blanched mint leaves respectively. These values are closed to the $E_{a}$ values reported by various researchers Arora et al., (2003) for drying of mushrooms e.g. $15-40 \mathrm{~kJ} / \mathrm{mol}$.

In conclusion, the mint leaves took 240 to 390 min to dry under tray drying to bring down initial moisture content (519.12 to 534.92 per cent) to final moisture content in the range of 5.40 to 5.94 per cent (db) at different studied temperatures. Among of five models, diffusion approach model satisfactorily described the thin layer drying of mint leaves.

Drying of mint leaves took place in falling rate period and constant rate period was completely absent. Moisture diffusivity of mint leaves dried under the tray dryer in the range of $3.29 \times 10^{-10} \mathrm{~m}^{2} / \mathrm{s}$ to $6.02 \times 10^{-10} \mathrm{~m}^{2} / \mathrm{s}$. Activation energy values of tray dried mint leaves found as 16.90 and $12.85 \mathrm{~kJ} / \mathrm{mol}$.

\section{References}

Aghbashlo, M., Kianmehr, M. H., Khani, S. and Ghasemi, M. 2009. Mathematical modelling of thin-layer drying of carrot. International Agrophysics, 23(4):313-317.

Akpinar, E. K. 2006. Mathematical modelling of thin layer drying process under open sun of some aromatic plants.
Journal of Food Engineering, 77(4):864-870.

Anonymous.2017, Horticulture statistics at glance, Ministry of Agriculture and Farmer welfare, GOI.

Arora, S., Shivhare, U. S., Ahmed, J. and Raghavan, G. S. V. 2003. Drying kinetics of Agaricus bisporus and Pleurotus florida mushrooms. Transactions-American Society of Agricultural Engineers, 46(3):721724.

Crank, J. 1975. The Mathematics of Diffusion $\left(2^{\text {nd }}\right.$ ed.) UK, Clearendon Press, Oxford.

Demir, V., Gunhan, T., Yagcioglu, A. K. and Degirmencioglu, A. 2004. Mathematical modelling and the determination of some quality parameters of air-dried bay leaves. Biosystems Engineering, 88(3):325335.

Doymaz, I. 2004. Drying kinetics of white mulberry. Journal of Food Engineering, 61(3):341-346.

Doymaz, I. 2006. Thin-layer drying behaviour of mint leaves. Journal of Food Engineering, 74(3):370-375.

Doymaz, I., Tugrul, N. and Pala, M. 2006. Drying characteristics of dill and parsley leaves. Journal of Food Engineering, 77:559-565.

Doymaz, İ., \& İsmail, O. (2011). Drying characteristics of sweet cherry. Food and bioproducts processing, 89(1), 31-38.

Goyal, R. K., Kingsly, A. R. P., Manikanthan, M.R. and Ilyas, S.M. 2007. Mathematical modelling of thin layer drying kinetics of plum in a tunnel dryer. Journal of Food Engineering, 79:176-180.

Kadam, D. M., Goyal, R. K., Singh, K. K. and Gupta, M. K. 2011. Thin layer convective drying of mint leaves. Journal of Medicinal Plants Research, 
5(2):164-170.

Pal, U. S. and Chakraverty, A. 1997. Thin layer convection drying of mushrooms. Energy Conversion, 38:107- 113.

Park K. J., Vohnikova, Z. and Brod, F. P. R., 2002. Evaluation of drying parameters and desorption isotherms of garden mint leaves. Journal Food Engineering, 51:193-199.

Porntewabancha, D. and Siriwongwilaichat, P. 2010. Effect of pre-treatments on drying characteristics and colour of dried lettuce leaves. Asian Journal Food Agro-Industry, 3(06):580-586.

Premi, M., Sharma, H. K., Sarkar, B. C. and Singh, C. 2010. Kinetics of drumstick leaves (Moringa oleifera) during convective drying. African journal of plant science, 4(10):391-400.

Ranganna S. 2000. Handbook of Analysis and quality control for fruits and vegetable products. Tata McGraw Hill Publishing Co. Ltd., New Delhi.

Silva, A. S., Almeida, F. D. A., Lima, E. E., Silva, F. L. H. and Gomes, J. P. 2008. Drying kinetics of coriander (Coriandrum sativum) leaf and stem cinéticas de secado de hoja y tallo de cilantro (Coriandrum sativum). CYTAJournal of Food, 6(1)13-19.

Singh, R. P. and Heldman, D. R. 2001. Introduction to food engineering. Gulf Professional Publishing.

Thompson, A, K. 2003. Fruits and vegetables (2nd ed.): 273. Oxford:Blackwell Publishing, UK.

Zakipour, E. and Hamidi, Z. 2011. Vacuum drying characteristics of some vegetables. Iran Journal of Chemistry and Chemical Engineering Research Note, 30(4):97-105.

\section{How to cite this article:}

Raviteja, G., P.S. Champawat, S.K. Jain and Sagar chavan. 2019. Drying Characteristics of Mint Leaves in Tray Dryer. Int.J.Curr.Microbiol.App.Sci. 8(03): 543-551.

doi: https://doi.org/10.20546/ijcmas.2019.803.066 